Cambridge Archaeological Journal

http://journals.cambridge.org/CAJ

Additional services for Cambridge Archaeological Journal:

Email alerts: $\underline{\text { Click here }}$

Subscriptions: Click here

Commercial reprints: $\underline{\text { Click here }}$

Terms of use : $\underline{\text { Click here }}$

\title{
Traditional Crafts: Learning by Doing
}

James Steele

Cambridge Archaeological Journal / Volume 7 / Issue 02 / October 1997, pp 314 - 316

DOI: 10.1017/S095977430000202X, Published online: 22 December 2008

Link to this article: http://journals.cambridge.org/abstract_S095977430000202X

How to cite this article:

James Steele (1997). Traditional Crafts: Learning by Doing. Cambridge Archaeological Journal, 7, pp 314-316 doi:10.1017/S095977430000202X

Request Permissions : Click here 
Traditional Crafts: Learning by Doing

Cognition and Tool Use: the Blacksmith at Work by Charles M. Keller \& Janet Dixon Keller, 1996.

Cambridge: Cambridge University Press; ISBN 0-521-55239-7 hardback, £35. xiv + 200 pp.

\section{James Steele}

The world is organized in societies but it is the individual who creates. First we learn by doing, later by reading. Learning by doing is concrete, the latter more abstract; working with tools and 
implements is creative and learning by practical doing as expressed in the artisan's skill means a humanization of work. (Lerche 1993, 228).

This book substantiates and enlarges Lerche's insight into the creative nature of traditional craft skills. Charles Keller is a cultural anthropologist with a background in archaeology, and Janet Dixon Keller is a cognitive anthropologist interested in the comparative organization of systems of knowledge. Their study documents the process of apprenticeship in artist-blacksmithing in the contemporary United States as experienced by a participant-ethnographer (Charles Keller), and outlines a general model of the acquisition and cognitive organization of technological know-how. In this, they make a strong case for the importance of conceptual reasoning processes, many of which are non-verbal: they are therefore critical of chaine opératoire approaches which focus on techniques and acts, but which neglect plans and knowledge systems.

Critics of the taxonomic approach to tool types will be heartened to learn that, at the outset, the Kellers realized that there was more to a smith's know-how than an organized set of tool categories: on the contrary, knowledge was to be understood as potentially reorganizable according to the task at hand, with categories capable of being redefined in shifting, flexible ways. The most frequently used tools, such as anvil and hammers, are also the most general-purpose ('tools of risk'), requiring substantial skill and dexterity for effective use: indeed, even the simplest tool is seen as multi-dimensional, with different aspects being used for different tasks. Among artist-blacksmiths there is evidently some suspicion of highly specialized tools - 'tools of certainty' - which produce a standardized effect suited for extensive, exact repetitive production, but which are seen as resulting in products which are 'cold', 'dead', 'untouched', and 'sterile'.

Part of the collective stock of knowledge of the artist-blacksmith community consists of a set of governing principles, which constitute axioms of a folk theory of their craft. These include the principles of transformation (production mostly involves transforming the shape and texture of material, not subtracting from or adding to it), of 'thinking hot' (heat is the general means to the transformative end), and of working freehand (they place a value on skill and on use of 'tools of risk'). Moving beyond the framework of ethnographic semantics, and also rejecting the method of detached observation of the chaine operatoire, the Kellers develop a model of technological knowledge which centres on the intentions and actions of the individual working within a framework defined by these governing principles. They see the individual's skill as residing in a dialectic movement from conceptual to material structures and back, guided by plans, constellations of knowledge, and by constant reassessment of the task in hand.

Extended accounts are given of the layout of two artist-blacksmiths' workshops. In a blacksmith's workshop, the smith's knowledge is reflected in the inventory and physical disposition of the tools which serve to facilitate accomplishment of desired ends. Thus, for instance, tools with similar functional potential and similar shapes are grouped together to be easily seen, and (for the most frequently used tools) so as to be easily reached from the core area in which the smith works. The layout of the shop contains a sort of generic 'activity signature', even if the particular stock of specific procedures employed by individual smiths cannot easily be inferred from it.

Production of an individual artefact depends on an umbrella plan which draws on the smith's stock of knowledge: it involves a design, and a conceptualization of means to this end. Undoubtedly, social expectations condition the outcome, but less as sets of rules than as a resource pool for the evaluation of designs, procedures and material results for a particular project. The umbrella plan is broken down into procedural steps, each of which is enabled by a constellation of procedural notions and material resources. Such constellations constitute 'hypotheses' about the specific means for achieving an immediate end within the framework of the umbrella plan, hypotheses which are verified or revised in practice. Where the product is novel, the initial design may be very vague and open to development in the course of production.

At the core of the conceptual organization of technological skill we find not verbal reasoning but imagery - visuospatial imagery especially, but also kinesthetic and aural imagery. This imagery is particularly hard to verbalize, but is deployed by the practitioner to represent general properties of materials, tools and procedures, aesthetic standards, and elements of umbrella plans and knowledge constellations. There are, it seems, limits on the amount of complex imagery which can be held in mind at any one time. One implication of the Kellers' project is that ethnographic studies of technology need to take seriously the participant half of 'participant observation'!

In a final discussion of their model, the Kellers propose that governing principles and constellations 
of knowledge can be seen to organize productive activity in other crafts, including pottery and weaving. They propose that the creativity which resides in the open-ended nature of craft learning remains in productive tension with the conservatism of traditional stocks of knowledge: their approach to the anthropology of knowledge thus allows humans (as producers of artefacts other than speech) a great flexibility and latitude in organizing their behaviour.

I recommend this book to anyone interested in social and cognitive aspects of non-industrial technologies. It should be widely read and discussed. Perhaps the choice of artist-blacksmithing as a focus for the study made the creative component of craft production unusually salient: but anyone working with chaine opératoire models of technical skill, or with ethnosemantic approaches to tool classification, will want to assess the arguments made against such frameworks in this coherent and purposeful account. Would that there were many more like it!

$$
\begin{array}{r}
\text { James Steele } \\
\text { Department of Archaeology } \\
\text { University of Southampton } \\
\text { Highfield } \\
\text { Southampton } \\
\text { S017 1BJ }
\end{array}
$$

\section{Reference}

Lerche, G., 1993. Documentation of traditional crafts, in Tools and Traditions, ed. H. Cheape. Edinburgh: National Museums of Scotland, 225-9. 